\title{
Counseling and Peers Effectively Overcome Anxiety of Adolescent Girl in Putri La Tahzanorphanage Yogyakarta
}

\author{
$* 1^{\text {st }}$ Sholaikhah Sulistyoningtyas \\ Faculty of Health Sciences \\ Universitas Aisyiyah Yogyakarta \\ Yogyakarta, Indonesia \\ tyassholaikhah@unisayogya.ac.ic
}

\author{
$2^{\text {nd }}$ Enny Fitriahadi \\ Faculty of Health Sciences \\ Universitas Aisyiyah Yogyakarta \\ Yogyakarta, Indonesia \\ ennyfitriahadi@unisayogya.ac.id
}

\begin{abstract}
Adolescence is puberty characterized by rapid physical changes, menarche, psychological changes and the emergence of secondary sex characteristics. This can cause feelings of confusion, various questions, fear and anxiety. This study aims to determine the effectiveness of counseling and peers in overcoming anxiety of adolescent girls in dealing with puberty. Type of experimental research, the population in this study were 52 people and the sample in this study used total sampling. The instrument used a questionnaire. Analysis using T-Test. The results showed that the significance value was 0,000 , which means that there was an effectiveness of counseling and peer assistance in overcoming adolescent girls' anxiety in dealing with puberty.
\end{abstract}

Keywords - anxiety of adolescent girls in dealing with puberty, counseling, peers

\section{INTRODUCTION}

Adolescence is a transitional period of development between childhood and adulthood characterized by biological, cognitive, and social changes. Adolescence lasts from the age of 12-21 years which are divided into: early adolescence (12-15 years), mid adolescence (15-18 years), and late adolescence (18-21 years). During this period a variety of changes occur in adolescence, one of which is physical changes. One of the tasks of an adolescent is to be able to accept his physical state and be able to use his body effectively [1].

Indonesia itself has been regulated according to Government Regulation of the Republic of Indonesia Number 25 of 2014 concerning child health efforts in Article 1 point 7 explaining that adolescents are children aged 10 years to 18 years. Since the Republic of Indonesia Government Regulation No. 25 of 2014 has not yet been ratified, at that time the Republic of Indonesia Regulations never classed adolescents but rather the ages of children and adults.

This is because the condition of adolescents who are in a transition phase, so they cannot be called neither adult nor children, it is implemented to minimize errors in delegating responsibilities of an adult individual, then the minimum adult limit (21 years) is the maximum age of adolescents whereas the minimum limit of adolescents begins when secondary changes occur in an individual [2].
A number of psychological changes accompany adolescent development or puberty. These changes involve body image. A strong desire for body image occurs during adolescence, but it becomes stronger in early adolescence when adolescents are more satisfied with their bodies than in late adolescence [1].

The acceptance behavior of new physical development and awareness of certain characteristics in them that are not owned and changed by others is one of the tasks of development as an adolescent to become an adult. Not a few children who have just entered puberty imagine their appearance would have been ideal if they had reached adulthood. Children are anxious about the physical parts that look different, teenagers see that one particular physical feature is very lacking, or not in accordance with the group sex. In this case, the anxiety of girls is greater than boys [3].

Changes at puberty will cause anxiety for adolescents who experience them. According to research by Isnatin (2015) adolescent girls' anxiety about physical changes during puberty is influenced by age, this can be shown that based on the results of the study, almost half of respondents aged 13 years were 34 people (44.7\%). At the age of 12-19 years old girls show physical changes as the body becomes enlarged. Adolescence tends to closed mind so that sometimes it causes excessive anxiety in adolescents and even experience stress. Anxiety is affected by this information it can be shown that $(53.9 \%)$ respondents never got information about physical changes at puberty [4]

The impact of physical changes experienced by young women if not in accordance with their growth can lead to negative stigma, which has psychological and social consequences, which will cause social anxiety, depression and negative body image, and low life satisfaction because they are more often rejected and ostracized. by his friends [5].

According to Hardianingsih research (2017), it was found that $30.4 \%$ experienced mild anxiety in dealing with anxiety in dealing with physical changes during puberty [3]. In a study conducted by Pratami (2017) the role of peers had a significant relationship in dealing with puberty anxiety levels. Besides peers who play a role in the level of anxiety 
in dealing with physical changes during puberty, namely the role of parents and the role of teachers [6].

Government efforts related to adolescent reproductive health include the provision of adolescent reproductive health services through the application of adolescent reproductive health services (PIK-R). The Ministry of Health also has the first few policies, namely the development of KRR (Adolescent Reproductive Health) [7].

Based on a preliminary study conducted at the Putri La Tahzan Orphanage in Yogyakarta, the number of adolescent girls were 59 people. 10 people were interviewed and 8 out of 10 people said they experienced anxiety in dealing with physical changes during puberty. One of anxieties is feeling afraid when first menstruating and afraid if the growth of the body is not appropriate.

\section{ANXIETY IN DEALING WITH PUBERTY}

Anxiety is a state of mood that is characterized by physical symptoms such as physical tension and worries about the future [8]. Anxiety can occur from the inability to face certain circumstances and negative views about the environment and the adolescents themselves.

\section{A. Impact of Anxiety}

The bad effects that occur if a person experiences excessive anxiety is reducing the body's immunity so it is difficult to prevent various diseases. Moreover, it can increase the onset of heart problems, due to the continuous stress resulting from excessive anxiety [9].

If the symptoms of anxiety occur under stressful conditions, it will damage physical and social functions if it cannot be helped properly, then anxiety disorders have the potential to cause serious problems [9].

\section{B. Anxiety Management}

Management of anxiety disorders in the stages of prevention and therapy requires a holistic approach, which covers physical, psychological, psychosocial and psychoreligious.

- Efforts to increase immunity to stress

- Psycho pharma Therapy

- Somatic Therapy

- Psychotherapy

- Psycho religious Therapy

In psychology adolescents are known as puberty, adolescence, and youth. Adolescence derived from the Latin "adolescere) which means growing toward maturity. Maturity in question is not only physical maturity but also social and psychological maturity (Kumalasari, 2012).

According to $\mathrm{WHO}$, adolescents are residents in the age range of 10-19 years, according to the Regulation of the Minister of Health of the Republic of Indonesia Number 25 of 2014, adolescents are residents in the age range of 10-18 years and according to the Population and Family Planning Agency (BKKBN) the age range of adolescents is 10-24 years and not married [7].

\section{RESEARCH METHOD}

This study uses an experimental analysis research that is a study conducted with the aim to determine the effectiveness of counseling and peer groups in overcoming adolescent girls' anxiety in dealing with puberty by measuring their pre-test and post-test [10]. The location or place of research will be conducted at Putri La Tahzan Orphanage, Yogyakarta City. Researchers took the place because based on the results of preliminary studies of young women who experience anxiety in dealing with puberty, 8 out of 10 adolescents were interviewed.

Based on the results of the preliminary study, researchers are interested in conducting research at Putri La Tahzan orphanage in Yogyakarta City. The sampling technique in this study uses a nonprobability sampling technique that is total sampling. The sample in this study amounted to 52 respondents. In this study the analysis used a T-Test to find out whether there was a difference between the groups given counseling with groups of peer groups.

\section{RESUlT AND DISCUSSION}

\section{A. Univariate Analysis}

TABLE I. CHARACTERISTICS OF RESPONDENTS BY AGE AND AGE OF MENARCHE

\begin{tabular}{ccc}
\hline Variable & Frequency & Percentage \\
\hline $\begin{array}{c}\text { Age of respondent } \\
\text { (years) }\end{array}$ & 0 & \\
11 & 11 & 0 \\
12 & 15 & 21.2 \\
13 & 9 & 28.8 \\
14 & 5 & 17.3 \\
15 & 12 & 9.6 \\
16 & & 23.1 \\
Age of menarche & 1 & \\
(years) & 11 & 1.9 \\
10 & 26 & 21.2 \\
11 & 11 & 50.0 \\
12 & 3 & 21.2 \\
13 & 0 & 5.8 \\
14 & 0 & 0 \\
15 & 52 & 0 \\
16 & & 100 \\
\hline Total & &
\end{tabular}

Based on table 1 the characteristics of respondents based on the age of the majority of respondents aged 15 years $(28.8 \%)$ while the majority of menarche age was 12 years old as many as $26(50.0 \%)$.

\section{B. Bivariate Analysis}

TABLE II. EFFECTIVENESS OF COUNSELING AND PEER ASSISTANCE IN OVERCOMING ADOLESCENT GIRLS' ANXIETY IN FACING PUBERTY

\begin{tabular}{lllllc}
\hline \multicolumn{1}{c}{ Treatment } & The mean & $\mathbf{N}$ & & Correlation & Sig \\
\hline Pre test & 1.9615 & 52 & 0.216 & 0,000 \\
Post test & 1.5385 & 52 & & \\
\hline
\end{tabular}

Based on table 2 states that after being analyzed using bivariate analysis using the t-test formula, the results were obtained that there were significant differences before intervening with the intervention being carried out with the 
results of a significance value of 0,000 which means there is effectiveness of counseling and peer assistance in overcoming anxiety of adolescent girls in dealing with puberty.

\section{1) Characteristics of respondents}

Characteristics of respondents based on the age of the majority of respondents aged 13 years by $15(28.8 \%)$ while the majority of menarche aged 12 years were $26(50.0 \%)$.

According to Sibagariang (2010) in the hormonal chapter in menstruation there are several cycles, as follows: hormonal cycle, during puberty the child grows quickly and gets a body shape that is typical for its type. Puberty (aqil baligh) changes occur in the ovaries that result in large changes in the entire body of a woman. Puberty occurs at the age of 12-16 years, influenced by heredity, nation, climate and environment. Menstruation is the release of the lining of the uterus (endometrium) accompanied by bleeding and occurs every month except during pregnancy. Menstruation that occurs every month is called the menstrual cycle. Menstruation usually occurs at the age of 11 years and lasts until menopause (usually occurs around the age of 45-55 years).

According to researcher in this study, anxiety in adolescent in the very first time or early menstruation can be influenced by age. Age determines someone's maturity level, the higher the age and experience of someone the lower the anxiety level experienced by her. Otherwise the lower the age and experience of someone the higher the anxiety level experienced by her. Anxiety can be reduced by getting information about puberty, especially menstruation.

2) The effectiveness of counseling and peer assistance in dealing with adolescent girls' anxiety in dealing with puberty.

Bivariate analysis using the t-test formula found that there were significant differences before the intervention and after the intervention carried out with the result of a significance value of 0,000 , which means there is an effectiveness of counseling and peer assistance in overcoming adolescent girls' anxiety in facing puberty.

Puberty is the transition of adolescents experiencing physical, emotional and psychological changes, physical development that is so prominent resulting in anxiety, this period of peers has a very important meaning [12].

Health education is a form of independent nursing action to help adolescents both individuals, groups, and the community in overcoming health problems through learning activities in which nurses as nurse educators [13]. Some ways to provide health education are through lectures, sociodrama forms and peer education methods. Several studies have shown that the lecture method that has been implemented has been less effective, so it is necessary to look for other methods in increasing knowledge and understanding [14].

The results of this study are supported by Risqa (2016) research on the Effects of Peer Education Health Education on Preparedness to Face Premenstrual Syndrome in Class VII and VIII Students at MTS Assalam Temanggung. The results show differences in the readiness to face premenstrual syndrome before being given health education through peer education and after being given health education through peer education. From the data analysis it is known that the $\mathrm{p}$ value is 0,000 [15]

The results of other studies by providing interventions in the form of health education about early menarche especially primary school age can change knowledge and know how to prevent things that are detrimental to health that have an impact on psychological problems such as fear and anxiety. The results of this study are the same as the study conducted by Widyarini who said that counseling about menarche was effective in reducing the level of student anxiety in dealing with menarche [16].

Isnaini's research (2011) similarly stated that there was a significant difference between the provision of health education to the decrease in anxiety facing menarche in grade 5 and 6 grade students of Ngoto Bantul State Primary School [4]. This is reinforced by the results of Yulia's research entitled the correlation between knowledge and the level of student anxiety in dealing with menarche in SD Negeri 03 Alai Padang which states that there is a significant correlation between knowledge and the level of anxiety in dealing with menarche [9].

This is in line with Wulandari's theory (2018) that peer support as information is given to individuals so that individuals feel loved, cared for, valued, and seen as relationships in communication and mutual responsibility [12].

Anxiety in dealing with puberty is a condition before menstruation which is characterized by feelings of fear accompanied by somatic signs, namely the occurrence of autonomic nervous system hyperactivity. Teenagers who experience puberty will be more depressed, worried, anxious, angry and crying just because of very little incitement [17]. This affects daily activities to be disrupted, for example at the time of menstruation becomes lazy to go to school (absent increases) so that teaching and learning activities decline.

Therefore, in the management of pre-treatment anxiety includes diet, aerobic exercise and relaxation therapy. Considering this, another solution is needed to reduce the anxiety experienced by young women. Provision of health education is a solution that is highly recommended to overcome this [18].

Anxiety that occurs in adolescents one of which is the result of physical changes. In addition, emotional and social changes also affect the psychology of adolescents who experience puberty [19]. According to Sujianti (2012), an important event during puberty of girls is the symptoms of menstruation or menstruation which is a biological sign of sexual maturity. Normally menstruation takes place at around the age of 11-16 years. Symptoms that often occur and are very striking in the first menstrual event is anxiety or fear strengthened by the desire to reject the physiological process. During the first menstrual period, sometimes erroneous assumptions arise that cause embarrassment, unclean or unclean feeling, feeling dirty and stained, and filled with other negative emotions [20].

According to researchers, adolescent girls are more worried about dealing with puberty, namely the transition from children to adulthood. Knowledge and openness of 
adolescents can affect adolescent psychology that causes anxiety. Based on research, young women are more worried about menstruation because they do not know deeply about menstruation, which are signs and symptoms of menstruation, things to do to prepare for pre-menstruation, ways to deal with leaks during menstruation. Good knowledge about menstruation in young women will be able to reduce the anxiety they experience. Adolescent openness to tell friends or parents especially mothers about menstruation can reduce the anxiety experienced by adolescents. This is an adaptive coping that is used by adolescents to overcome anxiety experienced. Mild anxiety can be overcome by coping like that. If increased anxiety can affect adolescent relationships toward deviant, because they do not know the ways used to overcome these anxieties.

\section{CONCLUSION}

Characteristics of respondents based on the age of the majority of respondents aged 13 years by 15 (28.8\%) while the majority of menarche aged 12 years were $26(50.0 \%)$. of counseling and peer groups in overcoming adolescent girls' anxiety in dealing with puberty, the result of bivariate analysis showed that significance value of $0,000 \quad 0,000$, which means there is an effectiveness of counseling and peer assistance in overcoming adolescent girls' anxiety in facing puberty.

\section{REFERENCES}

[1] Santrock. Perkembangan anak edisi 7 jilid 2. Jakarta : Erlangga. 2011.

[2] Kementerian Kesehatan RI. Pusat data dan informasi. Jakarta Selatan. 2014.

[3] Hardianingsih, Dani. Tingkat kecemasan remaja menghadapi perubahan fisik masa pubertas pada Siswi MTs Pondok Pesantren AsSalafiyyah Yogyakarta. Skripsi.Yogyakarta: Universitas 'Aisyiyah Yogyakarta. 2017.

[4] Isnaini. Perbedaan tingkat kecemasan terhadap menarche sebelum dan sesudah diberikan penyuluhan tentang mestruasi pada siswi Kelas 5 Dan 6 di SD Negeri Ngoto Bantul. STIKES Alma Ata Yogyakarta; 2011.

[5] Natsuaki. Going through tre rites of passage: timing and transition of menarche, childhood sexual abouse, and anxiety symptoms in girls. Journal of Youth Adolescence, 2011; 40, 1357-1370
[6] Pratami, Putri. Hubungan peran serta teman sebaya dengan tingkat stres dalam menghadapi tumbuh kembang pada masa remaja di MTS Negeri 1 Bantul. Skripsi. Yogyakarta: Universitas 'Aisyiyah Yogyakarta. 2017.

[7] BKKBN. Kajian profil penduduk remaja (10-24 tahun): Adapa apa dengan remaja. Policy Brief Puslitbang Kependudukn-BKKBN 2011;1. Jakarta

[8] Proverawati. Menarche menstruasi pertama penuh makna. Yogyakarta: Nuha Medika. 2019.

[9] Yulia AP.2015. Hubungan Pengetahuan dengan Tingkat Kecemasan Siswi dalam Menghadapi Menarche di Sd Negeri 03 Alai Padang. eSkripsi. Universitas Andalas. Universitas Andalas;.

[10] Sugiyono. Metode penelitian pendidikan (pendekatan kuantitatif, kualitatif, dan R\&D). Bandung: Alfabeta. 2016.

[11] Sibagariang, E. E., Pusmaika, R., \& Rismalinda. Kesehatan reproduksi wanita. Jakarta: Trans Info Media. 2010.

[12] Wulandari. Hubungan dukungan teman sebaya dengan kecemasan remaja putri dalam menghadapi perubahan fisik pada masa pubertas kelas VIII Di SLTPN 31 Semarang. Persatuan Perawat Nasional Indonesia Jawa Tengah e-ISSN: 2621-2994 Jurnal Ilmu Keperawatan Maternitas, Volume 1 No 1, Mei 2018, hal 15https://journal.ppnijateng.org/index.php/jikm

[13] Suliha,et al. Pendidikan kesehatan dalam keperawatan. Cetakan I. Jakarta : EGC. 2012.

[14] Murti, Prabandari dan Riyanto. Efektivitas promosi kesehatan dengan peer education pada kelompok dasawisma tersangka TB Paru. Jurnal Kedokteran Masyarakat. 2006.

[15] Risqa. Pengaruh pendidikan kesehatan peer education terhadap kesiapan menghadapi premenstrual syndrome pada siswi kelas VII dan VIII Di MTS Assalam Temanggung. (Jurnal).Yogyakarta.Universitas Aisyiyah Yogyakarta. 2016.

[16] Widyarini A. Efektivitas penyuluhan menstruasi terhadap tingkat kecemasan menghadapi menarche pada siswi usia 9-11 tahun di SDTI Ibnu Abbas Yogyakarta. Poltekkes Kebidanan Yogyakarta; 2011.

[17] Ganong, W.F. Buku Ajar Fisiologi Kedokteran.Jakarta:EGC. 2012.

[18] Proverawati. Menarche menstruasi pertama penuh makna. Yogyakarta: Nuha Medika. 2009

[19] Saputri. Tingkat kecemasan remaja putri yang mengalami masa pubertas Di SMP Negeri 1 Selorejo Kabupaten Blitar. Jurnal Ners dan Kebidanan, Volume 3, No. 3, Desember 2016 DOI: 10.26699/jnk.v3i3.ART.p298-303

[20] Sujianti. \& Dhamayanti, C. A. Buku Ajar Psikologi Kebidanan. Jakarta: Trans Info Media. 2012 